\title{
Elinor Ostrom: From Nepal Perspective
}

\section{Prachanda Pradhan}

$\mathbf{E}$ linor Ostrom (1933-2012), the first woman to win the Nobel Prize in Economic Science died of cancer on June 12, 2012 at the age of 78 in Bloomington, Indiana, USA. She was a great friend of Nepal who brought the as yet unrecognized natural heritage of Nepal to the attention of the world and founded her theory of common property resource management. Nepal's traditional system of managing local forest and water were recognized when Dr. Ostrom was awarded the Nobel Prize for Economic Science in 2009 for her study in Nepal of the management of the commons. Ostrom had often said that the prize actually belonged to the farmers of Nepal. She explained about the features of Farmer Managed Irrigation Systems (FMIS) in her Nobel Prize acceptance speech.

In 1988, she visited Nepal for the first time to study Decentralization, Finance and Management (DFM) under USAID program. Instead of the study of centralized decentralization in Nepal, she engaged herself in intense study and field work in natural resources management of FMIS and forestry resources management at the community level. Her first visit to Nepal became a very strong bond to continue further research on irrigation systems through her Ph.D students. Among them are Shu Yan Tang, Rita Hilton, Wai Fung Lam and Ashok Regmi. She had several students in forestry resources management.

She had travelled many parts of Nepal going up and down of the hills, interviewing the farmers, travelling to the Terai to look at the farmer managed systems. I would like to flash back the memory of 20 years ago while visiting an irrigation system in the Indrawati Watershed Basin with Dr. Ostrom. Near Bahunepati on the bank of the Indrawati River, getting herself ready by rolling knee up the trousers and taking off the shoes to ford the Indrawati River by naked feet in that cold winter morning to visit the Majha Kulo Irrigation System by climbing the hill on the other side of the river for the next one hour. Nothing prevented her to visit the irrigation systems and interact with the farmers. She was really a field worker and believed that we could learn a lot from the farmers and villagers. She strongly believed that we learn from the farmers and we have to give to the farmers what we have learnt; so, she propagated the idea "from farmer to farmer".

In connection with the research in Nepal, the most important activity that she initiated was the establishment of "Nepal Irrigation Institutions Database" in collaboration with the Institute of Agriculture and
Animal Sciences (IAAS), Tribhuvan University. The Database was established at IAAS, Rampur Nepal as well as in Indiana University, USA. They have been frequently updated. Both in Rampur and Indiana, the database became a precious mine deposit for active inquiring minds.

The Farmer Managed Irrigation Promotion Trust (FMIST of FMIPT) had the honor of recognizing her as "the ICON of FMIST" for her outstanding contribution to promote the knowledge on FMIS in 2002. Many scholars from Nepal had the opportunity to associate with her in the irrigation and forest resources management studies. She had jointly brought out a book with Mr. Ganesh Shivakoti on "Improving Irrigation Governance and Management in Nepal."

As promised in her lecture delivered during the welcome program to honor her as Noblel Laurieate jointly by the FMIST and JVS in December 2010 to bring out a book in collaboration with the Nepali colleagues, the book titled "Improving Irrigation in Asia: Sustainable Performance of an Innovative Intervention in Nepal" saw the light of day just nine months before her death.

Just before the death of Dr. Ostrom, she wrote to the Rio+ 20 Summit that one single agreement to resolve the long term sustainability of the planet would not work so there should be the provision of allowing the people to respond, which they have been doing, in a decentralized way. This can be termed as "Green from the Grassroots". She was the Chief Scientific Advisor to the Planet under the Pressure Conference.

Commoners and scholars in Nepal will remember Dr. Elinor Ostrom for many years.

1 Her experience of research in Nepal is briefly described in her article on "How FMIS Build Social Capital to outperform Agency Managed Irrigation Systems that Rely Primarily on Physical capital" in Prachanda Pradhan and Upendra Gautam (eds.), 2002. FMIS in Changed Context, Kathmandu: FMIST.

2 Ganesh Shivakoti and Elinor Ostrom (eds.), 2002. Improving Irrigation Governance and Management in Nepal, Okland, California: Institute for Contemporary Studies.

3 Elinor Ostrom, Wai Fung Lam, Prachanda Pradhan and Ganesh P. Shivakoti, 2011. Improving Irrigation in Asia: Sustainable Performance of an Innovative Intervention in Nepal, Cheltenham, UK and Northampton, MA, USA: Edward Elgar. 